\title{
Response of Sugar Beet Growth, Productivity and Quality to \\ Foliar Application of Different Forms of Boron Microelement and \\ Number of Sprays under New Reclaimed Soil Conditions
}

\author{
M.A. Abd El-Hady \\ Agronomy Department, Faculty of Agriculture, Ain Shams University, Cairo, Egypt.
}

$\mathbf{T}$

WO FIELD experiments were carried out in private farm (new reclaimed soil) at El Fayoum Governorate, Egypt during 2013/2014 and 2014/2015 growing seasons. These experiments aimed to study the effect of foliar application of different forms of boron microelement and number of sprays, i.e. control treatment (without), Borfam (one spray (I)), Borfam (two sprays (II)), Boric acid (one spray (I)), Boric acid (two sprays (II)), Borax (one spray (I)) and Borax (two sprays (II)) on growth, productivity and quality of sugar beet crop under new reclaimed soil conditions.

Results showed that:

- Sugar beet plants treated with Borfam treatment gave the highest values of effective root length, root diameter, root fresh weight, leaves fresh weight and root/leaves ratio (after 150 days from sowing) these values were $23.4(\mathrm{~cm}), 18.4(\mathrm{~cm}), 1410(\mathrm{~g} / \mathrm{plant}), 825(\mathrm{~g} /$ plant) and 1.71, respectively. On the other hand, the lowest values of the previous traits were recorded with the control treatment (without boron application).

- The results also showed that after 180 days from sowing Borfam (II) treatment recorded the highest values of root and leaves fresh weight, root/leaves ratio, root diameter, effective root length and photosynthetic pigments followed by Borfam (I).

- At harvest Borfam (II) treatment showed superiority in all root parameters, i.e. root diameter $(52.33 \mathrm{~cm})$, root length $(32.00 \mathrm{~cm})$ and root weight $(3755 \mathrm{~g} / \mathrm{plant})$.

- The highest values of root yield (34.63 ton/fad), top yield (7.773 ton/fad), sugar yield (6.00 ton/fad), sucrose percentage $(18.86 \%)$ and extractable sugar percentage $(17.33 \%)$ were recorded with Borfam (II) treatment followed by Borfam (I) treatment, while the lowest values were recorded with control treatment (without boron application).

Keywords: Sugar beet, Boron forms, Foliar application, Root, top and sugar yields, Quality.

\section{Introduction}

Sugar beet has become the first source of sugar production in Egypt compared to the sugar cane crop. The production of sugar beet in Egypt has been expanded vertically and horizontally to a great extent through the period from 1982 to 2016. Its productivity increased from 1.0 to 2.5 ton sugar/fad and its area from about 17 thousands to more than 545 thousands faddan in the same period. This sugar crop still has a great opportunity for expansion in Egypt for several reasons, such as sugar beet can grow under harsh environmental conditions such as salinity and drought in addition to complete the capacity of the existing factories and their future expansions mainly in the new reclaimed areas.

Sugar beet in common with other dicotyledon plants has a high boron requirements. This is related to higher proportions of compounds associated with the hemicullulose fraction and in lignin precursors. It must be able to take up sufficient quantities of the element to maintain a minimum concentration in tissue or growth will be disrupted. 
Boron plays an important role in the growth and productivity of many crops, especially sugar beet crop, which helps to accelerate the sugar translocation process. Cooke \& Scott (1993) recorded that boron is the most important trace element needed by sugar beet because without an adequate supply the yield and quality of roots are depressed. Allen \& Pilbeam (2007) emphasized that sugar beet crop has high requirements for boron when adequate boron nutrition is critical for high yield and quality of crops. They also reported that boron increases the rate of transport of sugars from source to sink. Abido (2012) reported that the advantage of boron application may be due to the function of boron in increasing plant metabolism, development and growth. El Sayed et al. (2011), found that increasing boron level caused significant increases in Chl "a", Chl "b" and carotenoids of sugar beet leaf. They also reported that these results could be attributed to that boron is an essential element for photosynthetic pigments. El-Geddawy \& Makhlouf (2015) found that there was a significant positive increase in root diameter and root length of sugar beet due to the gradual increase in the spraying concentration of boron from 105 to $210 \mathrm{ppm}$. They added that spraying sugar beet foliage by $210 \mathrm{ppm}$ produced the highest averages of root thickness. Kristek et al. ( 2006) studied the effect of foliar fertilization with fertina B element (1.0 kg B/ha ) on sugar beet productivity and quality. They reported that root and sugar yields were increased by $19.4 \%$ and $39.5 \%$ compared with control treatment.

This work was conducted to find out the optimal boron forms and number of sprays to attain the maximum root and sugar yields with the best quality traits of sugar beet crop grown under new reclaimed soil conditions.

\section{Materials and Methods}

Two field experiments were carried out during 2013/2014 and 2014/2015 growing seasons in private farm at, El-Fayoum Governorate. These experiments aimed to study the effect of foliar application of three boron forms, i.e. control (without), Borfam one spray (Borfam I), Borfam two sprays (Borfam II), Boric acid one spray (Boric acid
I), Boric two sprays (Boric II), Borax one spray (Borax I) and Borax two sprays (Borax II). Treatments were arranged in a complete randomized blocks design in 4 replicates. Seeds of sugar beet variety Ras poly were obtained from the Institute of sugar crops, Agriculture Research Center (ARC), Ministry of Agriculture, El-Giza, Egypt. Normal cultural practices for growing sugar beet crop were practiced properly as recommended in the region. Sugar beet seeds were planted in sandy soil under drip irrigation system. The experimental unit area was $16-\mathrm{m}^{2}$ consisted of 5 furrows each of $4 \mathrm{~m}$ in length and $80 \mathrm{~cm}$ apart, the distance between plants was $25 \mathrm{~cm}$.

\section{Boron foliar application}

Boron was added in three different forms and the concentration of spray solution was fixed at $300 \mathrm{ppm}$ boron as follows:

1. Sodium borate $(11 \%$ B) at rate 545 $\mathrm{gm} /$ fad one spray and two sprays.

2. Boric acid $\left(\mathrm{H}_{3} \mathrm{Bo}_{3}(17 \% \mathrm{~B})\right.$ at rate 352 $\mathrm{gm} /$ fad one spray and two sprays.

3. Borfam $(4 \% \mathrm{~B}+30 \%$ potassuim $)$ at rate $1.5 \mathrm{~L} /$ fad one spray and two sprays.

Boron was sprayed on sugar beet foliage after 140 and 170 days from sowing for each boron form.

Soil samples were taken at random from the experimental site at a depth of $0-30 \mathrm{~cm}$ and $30-60 \mathrm{~cm}$ from soil surface. The mechanical and chemical analyses of the experimental soil for the two growing seasons 2013/2014 and 2014/2015 are shown in Tables 1 and 2 .

\section{Data recorded}

Samples of 10 plants each were chosen at random from every treatment in the three replications to determine the following growth traits at the following two stages of growth, i.e. 150 and 180 days from sowing:

1. Fresh weight of leaves (g/plant).

2. Fresh weight of root (g/plant).

3. Root diameter $(\mathrm{cm})$

4. Effective root length $(\mathrm{cm})$

5. Root/shoot ratio $=$ root fresh weight $(\mathrm{g} /$ plant) / leaves fresh weight (g/plant)

6. Photosynthetic pigments: which were determined in the fresh leaves according to Wettestien (1957). 
TABLE 1. Mechanical analysis of the experimental soil (\%) for $2013 / 2014$ and $2014 / 2015$ seasons.

\begin{tabular}{|c|c|c|c|c|}
\hline Soil texture & Clay & Silt & Sand & Depth (cm) \\
\hline \multicolumn{5}{|c|}{ 2013/2014 growing seasons } \\
\hline Sandy & 4.3 & 5.6 & 90.1 & $0-30$ \\
\hline Sandy & 3.0 & 4.5 & 92.5 & $30-60$ \\
\hline \multicolumn{5}{|c|}{ 2014/2015 growing seasons } \\
\hline Sandy & 4.7 & 6.1 & 89.2 & $0-30$ \\
\hline Sandy & 4.4 & 5.1 & 90.5 & $30-60$ \\
\hline
\end{tabular}

TABLE 2. Chemical analysis of the experimental soil for $2013 / 2014$ and $2014 / 2015$ seasons.

\begin{tabular}{|c|c|c|c|c|c|c|c|c|c|}
\hline \multirow{2}{*}{$\begin{array}{r}\text { Depth } \\
\text { (cm) }\end{array}$} & \multicolumn{6}{|c|}{ Soluble cations and anions (meq/L) } & \multirow{2}{*}{ pH } & \multirow{2}{*}{$\begin{array}{c}\text { EC } \\
(\mathbf{d s} / \mathbf{m})\end{array}$} & \multirow{2}{*}{$\begin{array}{c}\mathrm{CaCo}_{3} \\
\%\end{array}$} \\
\hline & $\mathbf{C a}^{++}$ & $\mathbf{M g}^{++}$ & $\mathbf{N a}^{+}$ & $\mathbf{K}^{+}$ & $\mathrm{HCO}_{3}^{-}$ & $\mathrm{Cl}^{-}$ & & & \\
\hline \multicolumn{10}{|c|}{ 2013/2014 growing seasons } \\
\hline $0-30$ & 1.28 & 0.68 & 1.62 & 0.39 & 1.13 & 2.16 & 8.1 & 0.40 & 2.83 \\
\hline $30-60$ & 1.43 & 0.61 & 1.81 & 0.31 & 1.29 & 2.28 & 8.2 & 0.42 & 2.96 \\
\hline \multicolumn{10}{|c|}{ 2014/2015 growing seasons } \\
\hline $0-30$ & 1.29 & 0.71 & 1.59 & 0.41 & 1.12 & 2.11 & 8.0 & 0.39 & 2.85 \\
\hline $30-60$ & 1.41 & 0.63 & 1.83 & 0.33 & 1.27 & 2.18 & 8.1 & 0.42 & 2.93 \\
\hline
\end{tabular}

Data recorded at harvest (after 205 days from sowing)

At harvest (after 205 days from sowing) a sample of ten plants each were taken from the gardening rows to determine the following traits: Top weight ( $\mathrm{g} / \mathrm{plant}$ ), root weight (g/plant), root diameter $(\mathrm{cm})$ and root length $(\mathrm{cm})$.

Top yield (ton/fad): calculated from top weight of experimental unit) $\left(\mathrm{fad}=4200 \mathrm{~m}^{2}\right)$.

Root yield (ton/fad): calculated from root weight of experimental unit.

Biological yield $($ ton/fad $)=$ Top yield $($ ton/ fad) + Root yield (ton/fad).

Sugar yield (ton/fad): calculated according to the following equation:

Sugar yield $($ ton $/$ fad $)=$ extractable sugar $\% \mathrm{x}$ root yield (ton/fad)/100

\section{Quality measurements}

The chemical contents were determined by taken random samples of root tissues from the three replications to determine the following chemical components:
1. Sucrose percentage.

2. potassium $(\mathrm{K} \%)$ and sodium $(\mathrm{Na} \%)$ percentage in roots

3. Purity percentage.

4. Extractable sugar percentage (\%).

It were determined in El-Fayoum Sugar Company Laboratories at El-Fayoum Governorate.

\section{Statistical analysis}

The obtained data were exposed to the proper statistical analysis according to Snedecor \& Cochran (1967). The least significant differences (LSR) using Costat computer program V 6.303 (2004). LSR at 5\% level as significance was used to differentiate between means. Data of 2013/2014 and 2014/2015 growing seasons were subjected to homogeneity variance test. The test was not significant, so the combined analysis of the two seasons data was used.

\section{$\underline{\text { Results and Discussion }}$}

\section{Data recorded at 150 days}

Growth measurements after 150 days from sowing were estimated after the first spray of boron foliar as follows: 


\section{Root traits}

Data in Table 3 demonstrated the significant effects of boron forms on some root traits of sugar beet crop, i.e. (effective root length $(\mathrm{cm})$, root diameter $(\mathrm{cm})$ and root fresh weight (g/plant)). Data showed that sugar beet plants which treated with Borfam treatment gave the highest values of effective root length, root diameter and root fresh weight by $23.4(\mathrm{~cm}), 18.4(\mathrm{~cm})$ and 1410 (g/plant), respectively and showed superiority over the other two boron forms. The positive effect of boron may be due to its effective role in cell elongation of root (Makhlouf \& Khalil, 2017). Meanwhile the variations in effective root length between the treatments, i.e. control, Boric acid and Borax were not great enough to reach the significant level. Data also cleared that the control treatment recorded the lowest values of root diameter $(14.5 \mathrm{~cm})$ and root fresh weight (1076 g/plant).

TABLE 3. Effect of boron forms on root traits, leaves fresh weight (g/plant), root/leaves ratio and Photosynthetic pigments (mg/g. fresh weight) of sugar beet plants (after 150 days from sowing).

\begin{tabular}{lcccccccc}
\hline Treatments & $\begin{array}{c}\text { R. f. wt. } \\
\text { (g/plant) }\end{array}$ & $\begin{array}{c}\text { L. f. wt. } \\
\text { (g/plant) }\end{array}$ & $\begin{array}{c}\text { R/ L } \\
\text { ratio }\end{array}$ & $\begin{array}{c}\text { R. D } \\
(\mathbf{c m})\end{array}$ & $\begin{array}{c}\text { R. L } \\
(\mathbf{c m})\end{array}$ & \multicolumn{2}{c}{$\begin{array}{c}\text { Photosynthetic pigments } \\
\text { (mg/g fresh weight) }\end{array}$} \\
\hline $\begin{array}{l}\text { Control } \\
\text { (without) }\end{array}$ & $1076 \mathrm{e}$ & $718 \mathrm{~d}$ & $1.5 \mathrm{c}$ & $14.5 \mathrm{~d}$ & $15.4 \mathrm{~b}$ & $5.61 \mathrm{c}$ & $2.16 \mathrm{c}$ & $1.43 \mathrm{~d}$ \\
Borfam & $1410 \mathrm{a}$ & $825 \mathrm{a}$ & $\begin{array}{c}1.71 \mathrm{a} \\
\text { Chl. A }\end{array}$ & $18.4 \mathrm{a}$ & $17.4 \mathrm{a}$ & $6.72 \mathrm{a}$ & $2.95 \mathrm{a}$ & $2.18 \mathrm{a}$ \\
Boric acid & $1269 \mathrm{c}$ & $770 \mathrm{c}$ & $\begin{array}{c}1.65 \\
\mathrm{~b}\end{array}$ & $15.6 \mathrm{c}$ & $16.8 \mathrm{~b}$ & $6.17 \mathrm{~b}$ & $2.67 \mathrm{~b}$ & $2.01 \mathrm{~b}$ \\
Borax & $1302 \mathrm{~b}$ & $787 \mathrm{~b}$ & $\begin{array}{c}1.65 \\
\mathrm{~b}\end{array}$ & $16.4 \mathrm{~b}$ & $16.5 \mathrm{~b}$ & $6.25 \mathrm{~b}$ & $2.71 \mathrm{~b}$ & $1.84 \mathrm{c}$ \\
\hline
\end{tabular}

R.f.wt : Root fresh weight L.f.wt : Leaves fresh weight R/L: Root/leaves ratio R.D: Root diameter

R.L: Root length

\section{Leaves fresh weight (g/plant)}

Data in Table 3 pointed out that the effect of foliar spray of boron forms on leaves fresh weight was significant. Data also showed that sugar beet plants sprayed with Borfam gave the highest value (825 g/ plant) of leaves fresh weigh followed by Borax (787 $\mathrm{g} /$ plant) and Boric acid (770 g/plant) treatments. On the other hand, the control treatment recorded the lowest value $(718 \mathrm{~g} / \mathrm{plant})$. These results are in harmony with those obtained by Abido (2012) who reported that the advantage of boron application may be due to the function of boron in increasing plant metabolism, development and growth. Makhlouf \& Abd El-All (2017) found that increasing potassium fertilizer levels caused a significant increase in the values of leaf area index (LAI) of sugar beet plants and they reported that this result may be attributed to the role of potassium in increasing cell volume and hence increasing leaf area/plant.

\section{Root/leaves ratio}

Data in Table 3 and Fig. 1 revealed that root/leaves ratio responded significantly to foliar application of boron forms. Data showed that sugar beet plants treated with Borfam gave significantly the highest value (1.71) of root/leaves ratio compared with the other treatments. These results revealed that Borfam treatment encouraged root growth more than the growth of sugar beet leaves. Meanwhile the lowest value (1.5) of root/leaves ratio was recorded with the control treatment (without Boron).

\section{Photosynthetic pigments}

Data in Table 3 indicated that the boron forms attained significant effects on photosynthetic pigments, i.e. chlorophyll "a", "b" and carotenoids (mg/g fresh weight). Data cleared that sugar beet plants sprayed with Borfam recorded the highest values of chlorophyll "a", chlorophyll "b" and carotenoids by $(6.72,2.95$ and $2.18 \mathrm{mg} / \mathrm{g}$ fresh weight), respectively. Meanwhile, the control treatment gave the lowest values by (5.61, 2.16 and $1.43 \mathrm{mg} / \mathrm{g}$ fresh weight), respectively. Similar finding was found by El Sayed et al. (2011), who found that increasing boron level caused significant increases in Chl "a", Chl "b" and carotenoids of sugar beet leaf. They also reported that these results could be attributed to that boron is an essential element for photosynthetic pigments, where it increases rates of photosynthetic $\mathrm{O}_{2}$ evolution and $\mathrm{CO}_{2}$ fixation. Moreover, boron decreases the activities of oxidative pentose phosphate enzymes and respiration. 


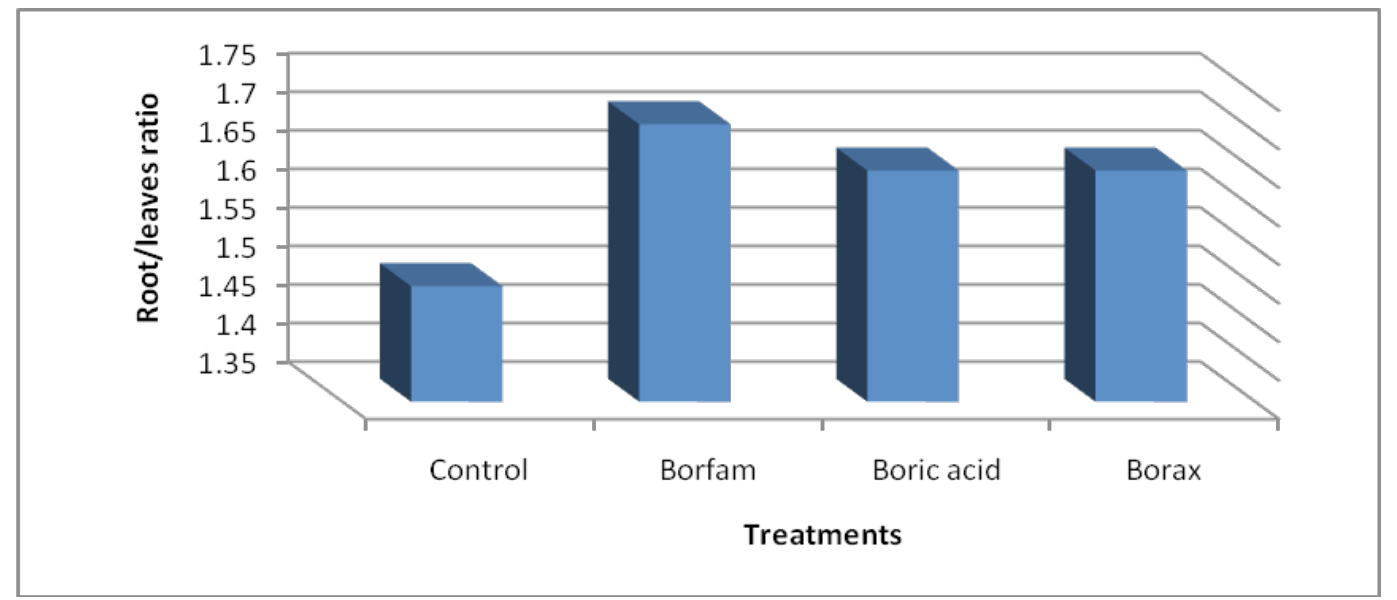

Fig .1. Impact of boron treatments on root/leaves ratio of sugar beet plants (after 150 days from sowing).

Data recorded after 180 days from sowing

Root traits

Results in Table 4 showed the significant effect of different foliar application forms of boron and number of sprays on some root traits of sugar beet under new reclaimed soil conditions. The response of all studied traits to two sprays of boron forms showed similar trends to that obtained with one spray presented in Table 3 . Results also showed the superiority of two sprays compared to one spray. This superiority hold fairly true with all traits under investigation. Sugar beet plants treated with two sprays of Borfam ( II) recorded the highest mean values of root fresh weight (2013 g/plant), root diameter $(35.6 \mathrm{~cm})$ and effective root length $(25.5 \mathrm{~cm})$ and the lowest mean values were obtained with the control treatment (without foliar applicaiton) by 1314 (g/plant), $22.6(\mathrm{~cm})$ and $17.7(\mathrm{~cm})$, respectively. The effect of number of sprays on all studied traits reached the significant level only with Borfam form. The significant variation between Borfam (I) and Borfam (II) treatments means that repeating spray process had positive effect on studied root traits of sugar beet plants. This finding is in agreement with that obtained by Enan (2011) who found that higher values of root traits and fresh weight/plant were obtained with increasing boron foliar application up to $200 \mathrm{ppm}$.

\section{Leaves fresh weight}

The data in Table 4 showed that leaves fresh weight (g/plant) of sugar beet (after 180 days from sowing) was significantly affected by the different forms of boron element as well as number of sprays. Results showed that Borfam
(II) treatment recorded the highest value $(933 \mathrm{~g} /$ plant) followed by Borfam (I) by (926 g/plant) and the lowest value (824 g/plant) was recorded with the control treatment. The effect of number of sprays of Boric acid was not great enough to reach the significant level.

\section{Root/leaves ratio}

Data presented in Table 4 and Fig. 2 showed that root/leaves ratio of sugar beet plants was significantly affected by boron treatments. Data also showed that Borfam (II) treatment was significantly superior in root/leaves ratio and recorded the highest value (2.16). All boron treatments exceeded to different extents the control treatment (subsequently, it was clear that greater share of biomass was mainly partitioned to root). On the other hand, the control treatment recorded the lowest value (1.59) of root/leaves ratio.

\section{Photosynthetic pigments}

Results in Table 4 demonstrated the significant effect of boron forms and number of foliar applications on photosynthetic pigments in sugar beet leaves after 180 days from sowing. All boron treatments increased significantly and to different extents for the studied photosynthetic pigments. Sugar beet plants sprayed twice by Borfam recorded the highest values of chlorophyll "a", chlorophyll "b" and carotenoids by 5.92, 2.76 and $1.93 \mathrm{mg} / \mathrm{g}$ fresh weight, respectively. The control treatment gave the lowest values by $4.21,1.87$ and $1.14 \mathrm{mg} / \mathrm{g}$. fresh weight, respectively. 
TABLE 4. Effect of boron forms and number of sprays on root traits, leaves fresh weight(g/plant) and photosynthetic pigments (mg/g fresh weight) of sugar beet plants (after 180 days from sowing).

\begin{tabular}{|c|c|c|c|c|c|c|c|c|}
\hline \multirow[t]{2}{*}{ Treatments } & \multirow{2}{*}{$\begin{array}{l}\text { R. f. } \\
\text { wt. (g/ } \\
\text { plant) }\end{array}$} & \multirow{2}{*}{$\begin{array}{l}\text { L. f. wt. } \\
\text { (g/plant) }\end{array}$} & \multirow{2}{*}{$\begin{array}{l}\mathrm{R} / \mathrm{L} \\
\text { ratio }\end{array}$} & \multirow{2}{*}{$\begin{array}{l}\text { Root } \\
\text { D. }\end{array}$} & \multirow{2}{*}{$\begin{array}{l}\text { Root } \\
\text { L. }\end{array}$} & \multicolumn{3}{|c|}{$\begin{array}{l}\text { Photosynthetic pigments } \\
\text { (mg/g fresh weight) }\end{array}$} \\
\hline & & & & & & Chl "a" & $\begin{array}{l}\text { Chl } \\
\text { "b" }\end{array}$ & Carot. \\
\hline $\begin{array}{l}\text { Control } \\
\text { (without) }\end{array}$ & $1314 \mathrm{e}$ & $824 \mathrm{e}$ & $1.59 \mathrm{e}$ & $22.6 \mathrm{e}$ & $17.7 \mathrm{f}$ & $4.21 \mathrm{f}$ & $1.87 \mathrm{f}$ & $1.14 \mathrm{~g}$ \\
\hline Borfam I & $1886 \mathrm{~b}$ & $926 \mathrm{ab}$ & $2.04 \mathrm{~b}$ & $30.7 \mathrm{~b}$ & $21.5 \mathrm{~b}$ & $5.72 \mathrm{~b}$ & $2.35 \mathrm{~d}$ & $1.85 \mathrm{~b}$ \\
\hline Borfam II & $2013 \mathrm{a}$ & $933 \mathrm{a}$ & $2.16 \mathrm{a}$ & $35.6 \mathrm{a}$ & $25.5 \mathrm{a}$ & $5.92 \mathrm{a}$ & $2.76 \mathrm{a}$ & $1.93 \mathrm{a}$ \\
\hline Boric acid I & $1658 \mathrm{~d}$ & $835 \mathrm{de}$ & $1.98 \mathrm{c}$ & $25.2 \mathrm{~d}$ & $18.4 \mathrm{e}$ & $4.93 \mathrm{~d}$ & $2.14 \mathrm{e}$ & $1.33 \mathrm{f}$ \\
\hline Boric acid II & $\begin{array}{c}1686 \\
\mathrm{~cd}\end{array}$ & $856 \mathrm{~cd}$ & $1.97 \mathrm{c}$ & $26.1 \mathrm{~d}$ & $19.2 \mathrm{~d}$ & $4.76 \mathrm{e}$ & $2.33 \mathrm{~d}$ & $1.40 \mathrm{e}$ \\
\hline Borax I & $1715 \mathrm{c}$ & $877 \mathrm{c}$ & $1.95 \mathrm{c}$ & $28.2 \mathrm{c}$ & $20.3 \mathrm{c}$ & $5.13 \mathrm{c}$ & $2.43 \mathrm{c}$ & $1.51 \mathrm{~d}$ \\
\hline Borax II & $\begin{array}{c}1684 \\
\mathrm{~cd}\end{array}$ & $907 \mathrm{~b}$ & $1.86 \mathrm{~d}$ & $28.5 \mathrm{c}$ & $21.5 \mathrm{~b}$ & $5.16 \mathrm{c}$ & $2.51 \mathrm{~b}$ & $1.64 \mathrm{c}$ \\
\hline
\end{tabular}

(I) One spray $\quad$ (II) Two sprays

R.f.wt. : Root fresh weight L.f.wt. : Leaves fresh weight

$\mathrm{R} / \mathrm{L}$ : root/leaves ratio R.D: root diameter

R.L: root length

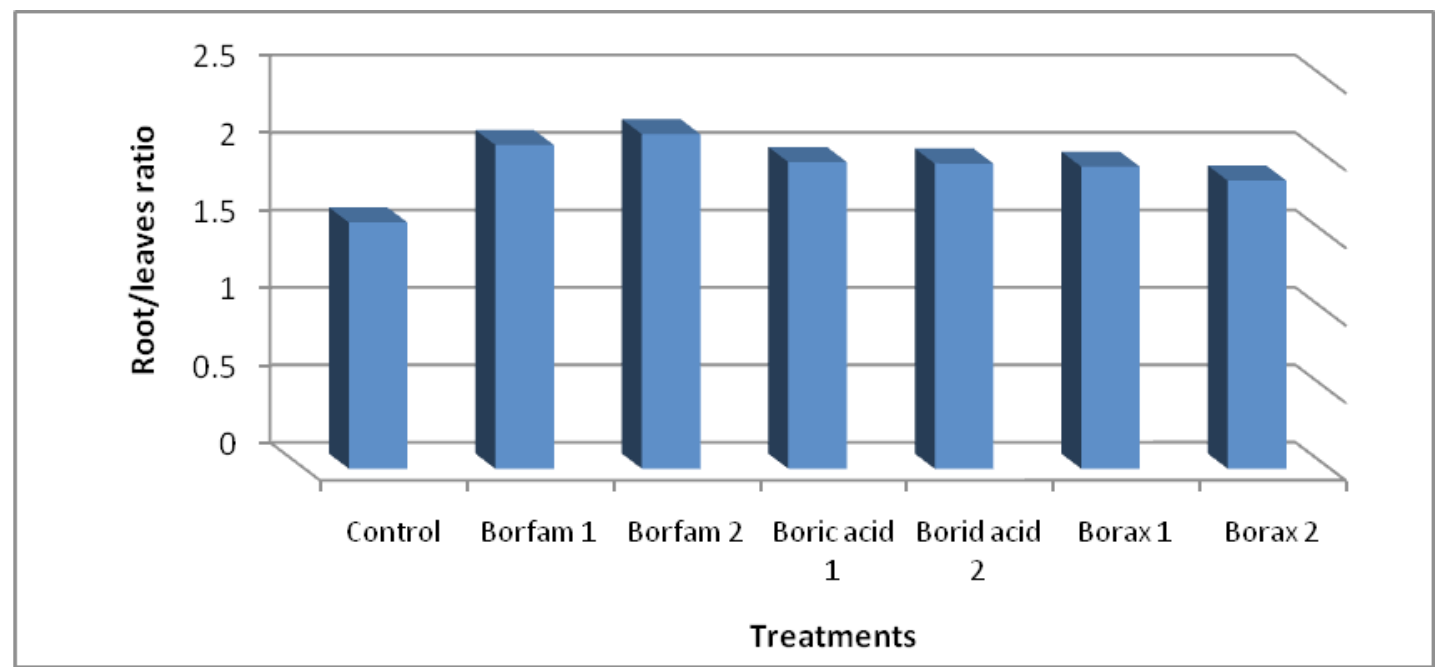

Fig. 2. Impact of boron treatments on root/leaves ratio of sugar beet plants (after 180 days from sowing) .

Data recorded at harvest (after 205 days from sowing)

Data in Table 5 showed the influence of born treatments on sugar beet root parameters and top weight at harvest under new reclaimed soil conditions. Data obtained cleared that root traits and top weight had significantly affected by boron forms as well as number of sprays. The highest values of root diameter $(\mathrm{cm})$, root length $(\mathrm{cm})$, root weight (g/plant) and top weight (g/plant) were recorded with Borfam (II) treatment. ElGeddawy \& Makhlouf (2015) found significant positive increase in root diameter and root length due to the gradual increase in the spraying concentration of boron from 105 to $210 \mathrm{ppm}$.
They also found that spraying sugar beet foliage by $210 \mathrm{ppm}$ produced the highest averages of root thickness. Abido (2012) reported that the relative advantage of boron element on root thickness may be due to the distinct role on photosynthates translocation process. Data also showed that the lowest values of root diameter $(30.33 \mathrm{~cm})$ and root length $(19.67 \mathrm{~cm})$ were recorded with the control treatment. While, the lowest values of root length were recorded at control and Boric (I) treatments by the same value $(19.67 \mathrm{~cm})$. On the same trend, the previous treatments gave the lowest values of root weight (2032 and $1985 \mathrm{~g} /$ plant, respectively). Concerning the influence of boron forms on top weight, the obtained results showed that sugar 
beet plants treated with Borfam (I) and Borfam (II) gave the highest values of top weight (1182 and $1177 \mathrm{~g} / \mathrm{plant}$, respectively) followed by Borax (II) (1151g/plant). These results could be attributed to containment of Borfam on potassium element and its role in increasing cell volume and hence increasing leaf area/plant (Makhlouf \& Abd El-all, 2017).

TABLE 5. Effect of boron forms and foliar number of sprays on root parameters and top weight of sugar beet at harvest.

\begin{tabular}{lcccc}
\hline Treatments & $\begin{array}{c}\text { Root diameter } \\
(\mathbf{c m})\end{array}$ & Root length $(\mathbf{c m})$ & Root & Top \\
\hline Control & $30.33 \mathrm{e}$ & $19.67 \mathrm{e}$ & $2032 \mathrm{f}$ & $953 \mathrm{c}$ \\
(Without) & $44.33 \mathrm{~b}$ & $29.00 \mathrm{~b}$ & $3334 \mathrm{~b}$ & $1182 \mathrm{a}$ \\
Borfam I & $52.33 \mathrm{a}$ & $32.00 \mathrm{a}$ & $3755 \mathrm{a}$ & $1177 \mathrm{a}$ \\
Borfam II & $35.33 \mathrm{~d}$ & $19.67 \mathrm{e}$ & $1985 \mathrm{f}$ & $828 \mathrm{~d}$ \\
Boric acid I & $34.33 \mathrm{~d}$ & $22.67 \mathrm{~d}$ & $2197 \mathrm{e}$ & $872 \mathrm{~cd}$ \\
Boric acid II & $40.00 \mathrm{c}$ & $24.67 \mathrm{c}$ & $2443 \mathrm{~d}$ & $1085 \mathrm{~b}$ \\
Borax I & $42.67 \mathrm{bc}$ & $27.67 \mathrm{~b}$ & $2846 \mathrm{c}$ & $1151 \mathrm{ab}$ \\
Borax II & &
\end{tabular}

\section{(I) One spray $\quad$ (II) Two sprays}

Results illustrated in Table 6 pointed out that root, top, biological and sugar yield of sugar beet were significantly affected by the different forms of boron as well as their number of sprays. Data revealed that sugar beet plants treated with Borfam (II) gave the highest values of root yield, top yield, biological yield and sugar yield (ton/fad). These values were $34.63,7.773,42.40$ and 6.5333 ton/fad, respectively, followed by borfam (I) treatment. On the other hand, the control treatment recorded the lowest values of root yield, top yield, biological yield and sugar yield (ton/fad) (21.66, 5.63, 27.29 and 3.863 ton/fad, respectively). Meanwhile, differences in sugar yield between control, boric acid (I) and borax (I) treatments were not significant. Gobarah \& Mekki (2005) found that boron application to sugar beet significantly increased root yield and its components as well as sugar yield. Pospisil et al (2005) reported that the application of $50 \mathrm{~L} / \mathrm{ha}$ of fortina $\mathrm{B}(3 \% \mathrm{~N}+$ $4 \%$ B) increased the root and sugar yield of sugar beet crop. Similar finding was found by Kristek et al. ( 2006) studied the effect of foliar fertilization with fertina B element ( $1.0 \mathrm{~kg} \mathrm{~B} / \mathrm{ha})$ on sugar beet productivity and quality and found that root and sugar yields were increased by $19.4 \%$ and $39.5 \%$ compared with control treatment (without). Allen \& Pilbeam (2007) emphasized that sugar beet crop has high requirements for boron when adequate boron nutrition is critical for high yield and quality of crops. They also reported that boron increases the rate of transport of sugars from source to sink. El-Geddawy \& Makhlouf (2015) found that increasing boron foliar application attained a significant response in the values of root fresh weight/plant. They also reported that this observation is due to the important role of boron in dry matter translocation and accumulation which in turn was reflected on the final root fresh weight.

TABLE 6. Effect of boron forms and foliar number of sprays on yield of sugar beet at harvest (after 205 days from sowing).

\begin{tabular}{lcccc}
\hline \multirow{2}{*}{ Treatments } & Root & top & Biological & Sugar \\
\hline Control & $21.66 \mathrm{f}$ & $5.63 \mathrm{e}$ & $27.29 \mathrm{f}$ & $3.49 \mathrm{~d}$ \\
(without) & $28.60 \mathrm{~b}$ & $7.483 \mathrm{ab}$ & $36.08 \mathrm{~b}$ & $4.65 \mathrm{~b}$ \\
Borfam (I) & $34.63 \mathrm{a}$ & $7.773 \mathrm{a}$ & $42.40 \mathrm{a}$ & $6.00 \mathrm{a}$ \\
Borfam (II) & $23.73 \mathrm{e}$ & $6.280 \mathrm{~d}$ & $30.01 \mathrm{e}$ & $3.75 \mathrm{~d}$ \\
Boric acid (I) & $25.53 \mathrm{~d}$ & $6.410 \mathrm{~d}$ & $31.94 \mathrm{~d}$ & $4.12 \mathrm{c}$ \\
Boric acid (II) & $25.17 \mathrm{~d}$ & $6.846 \mathrm{c}$ & $32.02 \mathrm{~d}$ & $3.65 \mathrm{~d}$ \\
Borax (I) & $27.08 \mathrm{c}$ & $7.296 \mathrm{~b}$ & $34.37 \mathrm{c}$ & $4.21 \mathrm{c}$ \\
Borax (II) & & & \\
\hline
\end{tabular}

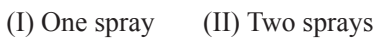




\section{Quality measurements}

Data in Table 7 point out the influence of deferent forms of boron foliar applications and number of sprays on some quality measurements of sugar beet roots. Data obtained showed that the highest value of sucrose percentage $(18.86 \%)$ was recorded at Borfam (II) treatment followed by Borfam (I) treatment, while the lowest value (16.1\%) was recorded with the control treatment. This observation is due to the important role of boron and potassium in sugar translocation and, in turn sugar storage and accumulation in sugar beet roots. This finding was agreement with that obtained by Enan (2011) who found that higher value of sucrose percentage was obtained with spraying boron at concentration $100 \mathrm{ppm}$. El-Geddawy \& Makhlouf (2015) investigated the effect of boron fertilizer levels on sucrose percentage in sugar beet roots and they found that there was significant increase in the values of sucrose $\%$ due to the increase in applied doses of boron fertilizer. Wang et al. (2015) reported that potassium $(\mathrm{K})$ is an essential nutrient required in higher amounts for plant metabolism especially for photosynthesis and assimilates transport. Concerning the effect of boron treatments application on potassium $(\mathrm{K} \%)$ and sodium $(\mathrm{Na} \%)$ percentage, data showed that the differences between boron forms application on $\mathrm{K} \%$ were not significant for all studied treatments. On the other hand, the values of $\mathrm{Na} \%$ differed greatly due to the different treatments of boron application. Data also cleared that Borax (II), Borax (I) and the control treatments recorded the highest values of $\mathrm{Na} \%$.

In respect to the influence of boron forms and their number of foliar spray on purity percentage, data in Table 7 obviously showed that Borfam (II) and Borfam (I) treatments recorded the highest values of purity percentage by 88.18 and $87.89 \%$, respectively. Data also showed that variations in purity percentage between the other treatments [control (without), Boric acid (I), Boric acid (II), Borax (I) and Borax (II)] were not great enough to reach the significant level. The importance role of boron element on purity $\%$ comes through its beneficial effect on the values of sucrose $\%$ (Table 7). This result is in agreement with that reported by Abido (2012) and El-Geddawy \& Makhlouf (2015).

Regarding the effect of boron forms and number of sprays on extractable sugar, data cleared that extractable sugar was significantly affected. The highest value $(17.33 \%)$ of extractable sugar pecentage was recorded with Borfam (II) treatment while the lowest value $(14.50 \%)$ was recorded with the control treatment.

TABLE 7. Effect of boron forms and foliar number of sprays on quality measurements of sugar beet roots (after 205 days from sowing).

\begin{tabular}{lccccc}
\hline Treatments & Sucrose \% & Potassium \% & Sodium \% & Purity \% & $\begin{array}{c}\text { Extractable } \\
\text { sugar \% }\end{array}$ \\
\hline Control (without) & $16.1 \mathrm{e}$ & $3.8 \mathrm{ab}$ & $2.00 \mathrm{ab}$ & $83.73 \mathrm{~b}$ & $14.50 \mathrm{~d}$ \\
Borfam (I) & $18.2 \mathrm{~b}$ & $4.10 \mathrm{ab}$ & $1.20 \mathrm{~d}$ & $87.89 \mathrm{a}$ & $16.27 \mathrm{~b}$ \\
Borfam (II) & $18.86 \mathrm{a}$ & $4.20 \mathrm{a}$ & $1.06 \mathrm{~d}$ & $88.18 \mathrm{a}$ & $17.33 \mathrm{a}$ \\
Boric acid (I) & $17.33 \mathrm{~cd}$ & $3.96 \mathrm{ab}$ & $1.60 \mathrm{c}$ & $85.27 \mathrm{~b}$ & $16.13 \mathrm{~b}$ \\
Boric acid (II) & $17.76 \mathrm{bc}$ & $3.8 \mathrm{ab}$ & $1.80 \mathrm{bc}$ & $85.89 \mathrm{~b}$ & $16.13 \mathrm{~b}$ \\
Borax (I) & $17.1 \mathrm{~d}$ & $3.63 \mathrm{~b}$ & $2.00 \mathrm{ab}$ & $84.06 \mathrm{~b}$ & $15.53 \mathrm{c}$ \\
Borax (II) & $17.83 \mathrm{bc}$ & $3.96 \mathrm{ab}$ & $2.12 \mathrm{a}$ & $84.49 \mathrm{~b}$ & $15.80 \mathrm{bc}$ \\
\hline
\end{tabular}

(I) One spray

(II) Two sprays

\section{Conclusion}

Under conditions of the present work, it was found that sprayed sugar plants with Borfam (II) can be recommended to get the highest root and sugar yields/fad.

\section{$\underline{\text { References }}$}

Abido, W.A.E. (2012) Sugar beet productivity as affected by foliar spraying with methanol and boron. International J. Agric. Sci. 4(7), 287-292. 
Allen, V. B. and Pilbeam, D.J. (Ed.) (2007) "Handbook of Plant Nutrition" (Books in Soils, Plants and the Environment). Boron by Umesh C. Gupta. pp. 241278.

Cooke, D.A. and Scott, R.K. (1993) "The Sugar Beet Crop". Chapman and Hall. London.

El-Geddawy, Dalia I.H. and Makhlouf, B.S.I. (2015) Effect of hill spacing and nitrogen and boron fertilization levels on yield and quality attributes in sugar beet. Minufia J. Agric. Res. 4(1), 959-980.

El Sayed, Safaa S.M., Abo El-Ghait, R.A. and Aboshady, K. (2011) Physiological response to foliar application of cobalt and boron on some physiological proprieties, yield and quality of sugar beet. Egypt. J. Appl. Sci. 26(12B), 859-874.

Enan, S.S.A.M. (2011) Effect of transplanting and foliage fertilization with potassium and boron on yield and quality traits of sugar beet sown under saline soil conditions. J. Bio. Chem. Environ. Sci. 6(2), 525-546.

Gobarah, Mirvate E. and Mekki, B.B. (2005) Influence of boron application on yield and juice quality of some sugar beet cultivars grown under saline soil conditions. J. Appl. Sci. Res. 1(5), 373-379.

Kristek, A., Stojic, B. and Kristek, Suzana (2006)
Effect of the foliar boron fertilization on sugar beet root yield and quality. Poljopriverda, 12(1), 22-26.

Makhlouf, B.S.I. and Abd El-All, A.E.A. (2017) Effect of deficit irrigation, nitrogen and potassium fertilization on sugar beet productivity in sandy soils. Minufia J. Plant Prod. 2, 325-346.

Makhlouf, B.S.I. and Khalil, S.R. (2017) Improvement of yield and quality of sugar beet sown at two dates by methanol and boron application. Minufia $J$. Plant Prod. 2, 305-324.

Pospisil, M., Pospisil, A. and Sito, S. (2005) Foliar application of liquid fertilizer Fertina B to sugar beet. Listy. Cukrovamike a Reparske, 121(5/6), 174-177.

Snedecor, G.W. and Cochran, W.G. (1982) "Statistical Methods". $7^{\text {th }}$ ed., pp. 511. Iowa State University Press, Ames, Iowa, U.S.A.

Wang, X. G., Hua, Z X., Hong, J.I.J., Shan, L.C., Qiu, C.D.W., Qiu, C.Y. and Yan, Y. H. (2015) Effects of potassium deficiency on photosynthesis and photoprotection mechanisms in soybean (Glycine $\max (\mathrm{L}$.$) Merr.). J. Integrative Agric. 14, 856-863.$

Wettestien, D.V. (1957) Chlorophyll -letal und from weehsel der plastiden. Exp. Cell Res. 12-427.

(Received 29 / $10 / 2017$ accepted 5 / $12 / 2017$ ) 


\section{استجابة نمو و إنتاجية و جودة بنجر السكر للرش الورقي بصور مختلفة من عنصر البورون وعدد مرات الرش تحت ظروف أرساضي الاستصلاح الجديدة}

محمد أحمد عبد الهادي قسم المحاصيل - كلية الزر اعة ألي - جامعة عين شمس - القاهرة - مصر.

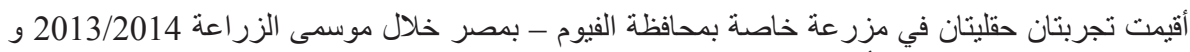

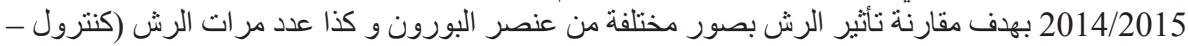

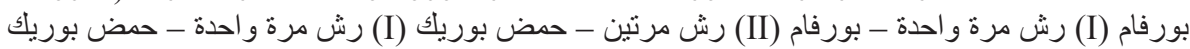

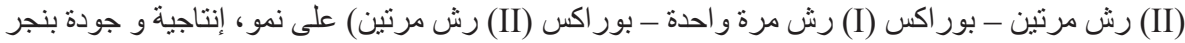
السكر تحت ظروف ار اضي الاستصلاح الجديدة ور كانت النتائج كالتالي:

• أعطت معاملة الرش بالبورفام أعلى القيم معنوية لصفات الطول الفعال للجذر (23,4 سم) ، قطر الجذر الفز

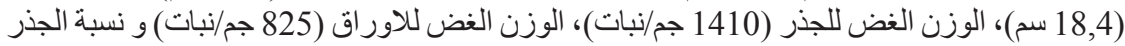

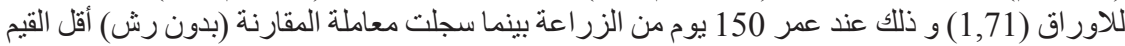
معنوية بالنسبة للقر اءات السابقة.

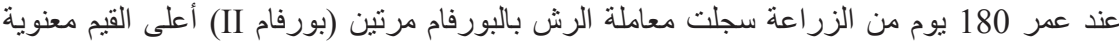

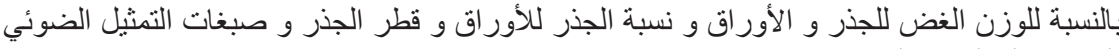

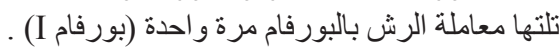

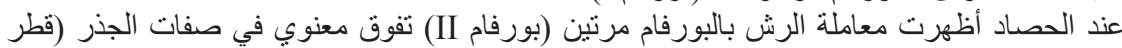

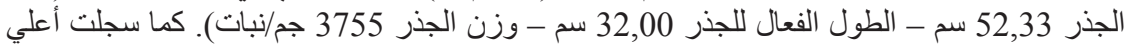

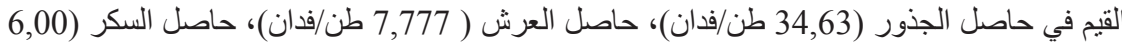

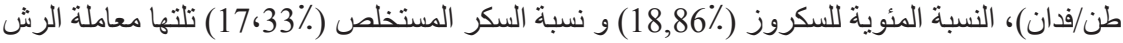
بالبورفام مرة واحدة (بورفام I) بينما سجلت معاملة المقارنة (بدون استخدام بورون (لقان ) القل القيم معنوية للقر اءات السابقة. 